\title{
Thresholds of Interpretation on the Threshold of Change: Paratexts in Late 19th-century Javanese Manuscripts
}

\author{
Ronit Ricci \\ The Australian National University, Canberra \\ ronit.ricci@anu.edu.au
}

\begin{abstract}
Gerard Genette's notion of the paratext as 'a threshold of interpretation' is employed in this article to explore a host of paratexts in late nineteenth century Javanese manuscripts from the Pura Pakualaman court library in Yogyakarta, Indonesia. Although paratexts were used in earlier years, especially in the form of illuminated opening pages, verse and metrical markers and some (often very brief) information about authors and scribes, the final decades of the nineteenth century and first two of the twentieth saw major shifts in the kind of paratexts employed, reflecting, I suggest, wider changes in practices of reading, writing and the transmission of knowledge.
\end{abstract}

Keywords

Java; literature; Pakualam; paratext; print; Yogyakarta; Indonesia

\section{Introduction}

At a time when we are on the verge of, or perhaps already deep into, a revolution in the way we read, write and process knowledge, and as we ponder the

I am grateful to the Asia Research Institute in Singapore for generously funding the research on which this article is based. Earlier versions of this article were presented at conferences in Singapore, the United States, Australia and the UK. I thank the audiences in all these places for their helpful comments and questions. Special thanks are due to Michael Feener, Annabel Teh Gallop, Sri Ratna Saktimulya and Ir. Rimawan for their suggestions and advice. I also thank B.R. Ay. Atika Suryodilogo of the Pura Pakualaman library (Perpustakaan Pura Pakualaman) for granting me permission to reproduce the images. Last but not least I am grateful to Jan Just Witkam for an unusually pleasant editorial process. 
difference between reading, for example, a blog and a book, it is instructive to glance back a century and examine another such transitional moment. This moment transpired towards the end of the nineteenth century in Java, a time of rapid social and political change. Such change was reflected, in part, in the ways manuscripts were produced, the significance attached to them, and the interactions between such hand written works and printed, published books. In this article, based on research at the Pakualam court library in Yogyakarta, I draw on Gerard Genette's notion of the paratext to explore some shifts in the ways Javanese manuscripts were written and arranged in the late nineteenth and early twentieth centuries, and consider the relationship between such changes and the larger questions of how practices of reading, writing, and knowledge transmission were shifting.

Java has a long and complex tradition of manuscript production. The Ramayana Kakawin, usually considered the earliest extant literary work in Javanese, dates from circa the ninth century, however the earliest surviving Javanese manuscripts date from the fourteenth or fifteenth century and most manuscripts we can access at present date from the nineteenth century. Although manuscripts were produced in diverse locales and contexts many of the manuscripts extant today are those collected in the royal courts of central Java where the existence of repositories or libraries of sorts improved the likelihood that manuscripts would survive the ravages of time, climate, and social upheaval. The research on which this article is based was conducted at one such location, the Pura Pakualaman library in Yogyakarta.

The Pakualam 'minor court' (Javanese: kadipaten) was the fourth and last court to emerge in central Java following the division of the Mataram kingdom in 1755. Founded in 1813 during the brief British rule of Java, it was the only court to have been established under British, rather than Dutch auspices, its founder Natakusuma (Pakualam I) having been rewarded by the British for his support. ${ }^{1}$

The Pura Pakualaman was known as an important center of culture, highly committed to the performing arts (especially dance) and the production of literary works. Among the latter emphasis was put on didactic works containing advice to younger princes, the children and grandchildren of successive bearers of the title Pakualam, and women. Islamic works

1 For a history of the court, based in large part on Dutch sources, see Soedarisman Poerwokoesoemo, Kadipaten Pakualaman. Yogyakarta: Gadjah Mada University Press, 1985 . 
that were written or copied in both Javanese and Arabic scripts (including classics like Tajusalatin, Ambiya and Menak), chronicles of Java's past, and local histories were also highly valued.

The time frame for manuscript production at the Pakualam court encompasses the years between the early-19th century (especially post 1813) and the 1940s, spanning one hundred twenty five years. I focus here on the later part of this period, the final years of manuscript production, from 1890 onwards. How were developments in the cultural, economic and social spheres during those turbulent decades reflected in the changing landscapes of compiling, writing, reading, translating and copying books? What can we learn about shifting conceptions of authority, memory, technology, faith and consciousness from examining them via the lens of manuscript culture and, more broadly, from drawing insight from the field of Book History? This article is intended as a brief and preliminary inquiry that purports to raise these questions and set the stage for addressing them further through future research.

\section{Paratexts: Thresholds of Interpretation}

In his monumental book, Paratexts: Thresholds of Interpretation, literary scholar and critic Gerard Genette explored those bits of text such as the author's name, the title, preface and illustrations - to name a few - that surround and extend the text and present it to its readers. ${ }^{2}$ Not only did Genette consider paratexts as productions that envelop the text or frame it, but he also proposed the more specific notion of paratexts as entry points to, or thresholds of any text that one encounters:

More than a boundary or a sealed border, the paratext is, rather, a threshold ... that offers the world at large the possibility of either stepping inside or turning back... It is an 'undefined zone' between the inside and outside... an edge... a fringe of the printed text which in reality controls one's whole reading of the text. ${ }^{3}$

2 Gerard Genette, Paratexts: Thresholds of Interpretation. trans. Jane E. Lewin (Cambridge: Cambridge University Press, 1997).

3 Genette, Paratexts 1. 
For example, a provocative title may cause a potential reader to pick up a book by an obscure author, while a translator's note may shape readers' interpretation of a novel by introducing them to the author's life history and her circumstances of writing.

Genette wrote a synchronic, not a diachronic study: an attempt at a general picture, not a history of the paratext. He felt it important to define the object before studying its evolution, articulating the categories of the paratextual field which had been disregarded or misperceived. Due to his own expertise Genette very consciously did not go beyond the bounds of Western (mostly French) literature. Since its publication, however, the influence of his paratextual analysis has been remarkably diverse, shaping lines of inquiry not only in Western and non-Western textual studies but also scholarship in a range of fields and topics including, among others, media studies (Gray 2008), gender (Nixon 2002), indexing and classification (Paling 2002), racial relations (McCoy 2006) and historical explorations of writing (Hernandez 2009). Extending Genette's influence in yet another direction I employ his paratextual model in the following pages as a useful and insightful lens through which to consider change in Javanese manuscripts.

\section{Javanese Manuscripts and Paratextual Markers}

The way writing is laid out on Javanese manuscripts' pages can at times seem impenetrable. The text begins on the top left hand side of the first page and often continues, dense, for many pages to come. Although most texts were written in metrical verse (tembang) the transitions from one stanza (pada) to the next, and from one canto (pupuh) to the next, were not always clearly marked in a reader friendly manner. Often the only way to know a text's content is to read it, or recite it, and skimming is not an option. The paratexts of title, author, table of content, chapter headings and the like that can provide a quick sense of what a text is about-and that we have come to expect in a modern book-were not often employed. However, certain kinds of paratexts were nonetheless added to manuscripts with the goal of facilitating recitation and/or for aesthetic value. Different paratexts anticipated, or framed, different aspects of the texts for its reciter or reader, directing them and enhancing the experience of engagement with the text. 


\section{Traditional Paratexts}

Several paratextual markers appear in nineteenth century manuscripts from the Pakualam court. Among them is the gapura renggan ('adorned gateway') or opening pages, typically facing each other, that sometimes contained details of an author or scribe, date and time of inscription. The latter could indicate the day of the week and time of day, but not necessarily the year of inscription. Such opening pages were often (as the term indicates) beautifully illuminated, adorned with colorful birds, mythical nagas, flowers and geometric designs. An example is found in the Babad Pakualaman, a 964-page history of the court that depicts Pakualam I's anointment, Raffles' visit to Yogyakarta and many other events, ending with Pakualam I's death and succession by his son. Written in 1918 on the request of PA VI it was probably the last manuscript of its kind to be produced at the court (see fig. 1).

A favored Pakualaman paratext is the small circular or square-shaped space known nowadays as rubrikasi that appeared on page margins. The spaces were framed with simple black lines or, in the more elaborate manuscripts, with color, gold and some illustration, and contained brief indications of what a particular passage was about. For example, in the case of the Babad Pakualaman, the succinct text might read 'Mt. Merapi erupts' (ardi Merapi murub), 'the Governor and Admiral arrive in Yogyakarta' (Gubernur lan admiral rawuh angayogya), or 'the Sultan of Surakarta passes away' (kangjeng Sunan Surakarta seda, see fig. 2).

The use of the rubrikasi was very likely inspired by practices of copying the Qur'an, where similar shapes appeared on page margins, indicating Qur'anic divisions. Among the latter the juz' (marking the division of the Qur'an into thirty parts), was especially important in local traditions of the archipelago. ${ }^{4}$ Perhaps even more strikingly reminiscent of the rubrikasi are the illuminated forms found in Qur'ans from Sumatra, Banten, Malaysia's East Coast and Pontianak that indicate text divisions selected for recitation, known as maqra', and appear to be unique to Southeast Asia. ${ }^{5}$

4 Gallop, Annabel Teh and Ali Akbar. 'The Art of the Qur'an in Banten. Calligraphy and Illumination' in Archipel 72 (2006): 117.

5 Gallop, Annabel Teh. 'The Art of the Qur'an in Southeast Asia.' In Fahmida Suleman, ed. Word of God, Art of Man: The Qur'an and its Creative Expressions (Oxford: Oxford University Press, 2008) 195. Gallop's pioneering studies have contributed significantly to our understanding of local traditions of copying and illuminating the Qur'an across Southeast Asia. For an example from the southern 
However similar the rubrikasi to earlier paratextual forms, its use in late nineteenth and early twentieth century manuscripts had new uses and meaning. The brief information presented within the rubrikasi certainly offered clues to the reciter as he progressed through the text but may also point to an emergent practice of silent reading or of skimming the manuscript's pages in search of particular events or stories that a reader wished to locate. In this sense the rubrikasi can be viewed as a form of a table of contents that was scattered throughout a book's pages rather than positioned at its start. Thus a paratext that echoed with a prior tradition and with the copying of the sacred Book was appropriate also for shifting reading practices.

Another common paratext, also reminiscent of the way Qur'ans were copied, was the often gilded or colorful image indicating the end of each canto as well as, in the most elaborate creations, the end of each stanza. ${ }^{6}$ These flower, bird, and leaf-shaped markers helped guide the reciter through the verses and, with the metric change at canto's end, indicated also a shift in mood, emphasis or theme that would have been familiar to reciter and audience. Tellingly, in the 1899 Lokapala, the more typical floral and faunal motifs were replaced with letters - not Javanese but Latin ones - indicating both the end of each stanza and the name of the poetic meter, thus $\mathrm{P}$ for pangkur and $\mathrm{K}$ for kinanthi (see fig. 3). This kind of 'metric paratext' affected recitation above all, whereas the rubrikasi was more closely linked with content. And indeed these two paratextual forms point to different, albeit complementary dimensions of textual engagement (see fig. 2).

As these examples show, paratexts were clearly not unheard of at the Pakualam court in the early and mid nineteenth century and they provided certain types of information, guidance and framing to reciters and audiences. However, as the nineteenth century progressed and especially in its final one or two decades, additional paratexts were introduced into Javanese manuscripts, several of which I wish to explore.

Philippines see her 'Qur'an Manuscripts from Mindanao in U.S Collections'. Our Own Voice website, April 2011. http://www.oovrag.com/essays/essay2011a-1.shtml

${ }^{6}$ In the case of the Qur'an round verse markers outlined in black or red ink are found often. More elaborate such markers in the form of flowers are quite rare in the Malay World but very common in Ottoman, Indian and Persian Qur'ans. See Gallop, The Art of the Qur'an, 192-193. 


\section{Shifting Paratexts}

Let us begin at the beginning: a manuscript's title page (if there was one at all) tended to include the title of the work, often appearing as part of an initial written section that included additional information like the year and place of inscription, the author or scribe's name. However, in some cases the title page more closely resembled current conventions with a title appearing in the upper or central part of the page, written in large and/or bold letters, standing on its own or with an author's name. For example, the 1908 Dara Murtasiyah's title page presents the title on its top central part, and then lists its owner, scribe, and dates of the writing's commencement and completion beneath it (see fig. 4).

The opening page of the 1891 Babad Napoleyon does not indicate its title but it does mention the place of inscription as well as its date according to both the Javanese and European time reckoning systems. Interestingly, the only word highlighted through the use of darker ink on this page is the author's name, Sasradiwirya. Even his high status title, Radèn Mas, which directly precedes his name on the page, is written in the light ink used for the rest of the text. This emphasis raises the question of how notions of individual authorship may have been changing, with more importance given to the person who composed the work and to his ownership_-via a highlighted, permanent inscription of his name-over it. ${ }^{7}$ Also noteworthy is the use of the verb nganggit to describe Sasradiwirya's accomplishment as it has a range of meanings including arranging, writing, composing and inventing. We cannot be certain as to its precise nuances here but, again, it may have evoked a certain sense of creation or invention (even if it related to the writing anew of an older text) that was being linked to a particular author. This in the context of many earlier Javanese works written by anonymous authors who often acknowledged that they are re-telling the stories 'of old', tales 'coming from the Arab lands', or otherwise basing themselves on prior but unspecified authorities (see fig. 5).

Another paratext that seems to emerge during this period is a form of synopsis that appears on the opening page. Offering a brief description of the manuscript's content, it represents an alternative to the conventional

7 The Javanese reads babonipun anggitanipun Radèn Mas Sasradiwirya (capitalization added), which could refer to Radèn Mas Sasradiwirya as composing (nganggit) this manuscript, or to his composing the original (on which this exemplar is based). The word babon can refer to both. 
table of contents common in modern books as well as to the one discussed above made up of rubrikasi scattered along the margins of a text, indicating particular developments within its narrative. The synopsis does not indicate where in the manuscript a certain event will be depicted nor how much space is dedicated to this or that detail but rather presents a minimal outline informing the reader or listener of what to expect in the broadest of terms. It states the starting point of events as well as their end point so that those familiar with the story (as many would be) could know how far this particular volume would take them within the story's realm and which events and personalities would certainly not be covered. Thus the Serat Aji Pamasa opens with seven brief lines informing its audience that the volume depicts the adventures of king Kusumawicitra, ruler of Kedhiri, and those of additional kings, and concludes with Kusumawicitra moving his kingdom to Penggil.

The first volume of Babad Segaluh, inscribed a year later in 1897, similarly includes a synopsis but this one is even briefer, just two sentences, stating that the work relates the life history of king Banjaransari of Segaluh until the time of king Siyungwanara's birth in Pajajaran. After this short introductory sentence and the dates of commencing and concluding the writing, and before mentioning his own name, the scribe Jayengkusuma calculated the number of days between the dates of beginning and end of the manuscripts production and noted them as well: dadosipun dipungarap 45 dinten ('it was composed, made, in 45 days').

At volume's end is a small but significant paratext indicating that the text has not yet concluded and will commence anew in the next volume. The Javanese, which could be translated as 'to be continued', reads: teksih wonten candhakipun, followed by wonten jilidan ingkang nomer loro ('in volume \#2'). ${ }^{8}$ This paratext creates a clear, almost concrete link across manuscripts, so that they cannot be seen as separate entities but as elements within a larger, connected whole that may be a small series, a collection or a broad writing tradition.

Numerals - used for marking pages, chapters, sections and the likealso constitute a paratext with important functions. Numerals do not necessarily appear in the opening and closing pages as do the paratexts

8 Babad Betawi volume 2, written in the 1820 s, contains a small, now almost imperceptible mark - a square surrounding the words indicating the existence of a candhakan (continuation). This paratext therefore existed during an earlier period but was neither as visible nor as detailed as in later ones. 
discussed thus far and can be scattered within the text in a variety of ways. Several manuscripts include more than a single count, employing numerals to systematically follow the accumulation of pages, cantos (pupuh) and stanzas (bait or pada). In the Babad Segaluh Javanese letters mark the page number on top and the canto number on the bottom, while the stanza number is indicated on the margins (see fig. 6).

Similarly page, canto and stanza (within the particular canto) are marked in the 1928 Panji Jayengtilam, in this case using Roman numerals rather than Javanese letters.

Although the numbering of pages in a sequential manner appears in many earlier manuscripts, this highly orderly way of committing the text to the page and the clear visibility of canto and stanza positions that allow the reciter or reader to constantly know where they are located, so to speak, within a kind of linear space' of the text, stands in contrast to the often less distinct and continuous flow of words and verses that was typical of much writing. It points to an organizing impulse and an emphasis on precision which becomes even more evident in the pratélan (literally: list, information).

We can consider the paratext of pratélan as a 'summary of metrical statistics'. Several manuscripts produced in the final years of the nineteenth century and first years of the twentieth in the Pakualam court contain such summaries. Appearing at the end of the manuscript, usually in the inner side of their back cover, they consist of charts that record and quantify various aspects of the manuscript's writing. For example, the 1897 Panji Panuba lists the names for the meters (namining tembang) in their order of appearance, the number of stanzas per canto (pada sapupuh), the number of Javanese script diacritical marks denoting vowels (dhawahing padalingsa, further divided into five sections), ${ }^{9}$ the total of vowel marks per stanza and canto (gunggung ing padalingsa), and the grand total of syllables per stanza and canto (gunggung ing wewanda). The bottom of this numbers-filled chart includes a category of gunggung ('total') that lists the number of stanzas and syllables contained in the entire manuscript (see fig. 7).

What might these charts suggest? They seem to indicate a certain preoccupation, or perhaps obsession with enumerating, calculating, and documenting, and they convey a message of accuracy and precision. Through their clearly marked divisions and categories they tell us something about

9 Legena (without any vowel-indicating diacritic), ulu ( mark denoting the vowel 'i'), suku (mark denoting the vowel ' $u$ '), taling (diacritical mark denoting 'e'), taling tarung (diacritical mark denoting 'o'). 
the kind of information deemed valuable or necessary in approaching the manuscripts. They also open a window to how such information was stored and remembered, indeed to the view that it was important to store it in writing at all as a kind of index or glossary that, to the initiated, could reveal something of the manuscript's inner workings. The insight offered by the pratélan could be of a technical-structural sort-the manuscript's length, number of metrical shifts and vowel usage - or of a more substantial nature through the assessment of metric choice (with particular moods and scenes' associations to certain meters), the complexity of the metrical scheme and the extent to which a poet employed a range of tembang in a creative or unusual way. Above all, because of their preoccupation with metrics, these charts seem to point to a process of codifying, quantifying and standardizing the tembang into a scientific-like model.

\section{Manuscripts and Print-Shifting Interactions}

I have examined several paratexts that appeared with increasing frequency in the later years of manuscript production in the Pakualam court of central Java. One obvious question raised by this exploration touches upon the relationship between visible changes in the manuscripts and the rise of print culture in Java throughout the nineteenth century, accelerating towards its final decades. The period for which I consider the Pakualam manuscripts came after over twenty five years of newspaper circulation, printed books and, to a lesser degree but still significant, the emergence of reading clubs and lending libraries. ${ }^{10}$ All these developments are in the background as we consider the manuscripts and assess change unfolding in terms of writing practices, reading, script usage, language choice and education.

Many books in late nineteenth and early twentieth century Java consisted of print versions of manuscripts. This was certainly the case with publications by Balai Pustaka (founded in 1917 by the colonial government of the Dutch East Indies), which published a host of Javanese literary 'classics' in Javanese script. Often the printed text was much more accessible than the handwriting of the manuscripts due to its organized and clear appearance on the page. In the Pakualam court however, a reverse or coun-

10 On such a library in nineteenth century Sumatra see Kratz, E. U. 'Running a lending library in Palembang in 1886 AD', in Indonesia Circle 14 (1977), 3-12. 
ter trend of sorts is apparent, when printed books were sometimes copied (or copied back) into manuscript form. Examples include Serat Sri Yatna (copied in 1941 from a 1932 book published by Panti Pradipta), Pakem Taruguna and Paniti Sastra (copied from a 1892 book).

Also intriguing is the relationship between manuscripts and another print media, namely the newspapers. Bramartani, first printed in $1855^{-56}$ and again in 1864-1932 as Jurumartani, was the first vernacular newspaper in the Dutch East Indies. The manuscript Kempalan Warni-Warni which, as its title indicates, was a collection of various writings, cites an $1883 \mathrm{Brama}$ rtani issue that discussed matters related to the Javanese dating system (pethikan saking Bramartani taun 1883 angka 27, see fig. 8).

Several such instances are found in the collection: the undated Babad Sengkala is based on a story published in Bramartani on March 22, 1888. The scribe of the 1897 Panji Panuba took care to mention that the story previously appeared in the Jawi Kandha, a Malay-Javanese thrice-weekly newspaper that first appeared in 1891 from the printing press of A. Schultz in Surakarta and was one of the first Indies' newspapers to recruit an Indonesian editor. ${ }^{11}$ Significantly, a poem by Pakualam III was published in $\mathrm{Bra}$ martani in 1865 . Such developments suggest changing patterns of authority and respectability between manuscript and book cultures and, more generally, highlight the linked worlds of print and manuscript literary production during this period.

Before concluding I would like to point very briefly to one final paratext: illustrations. In a revered Javanese text and source of many a wayang (shadow puppet theater) performance, the Serat Baratayuda, an illustrator portrayed scenes of the great war of the Mahabharata. In an exemplar from $185^{0}$ the warriors are sitting atop elephants and holding on to their swords (see fig. 9). Although their dress is mostly European the atmosphere of the scene is rather archaic. Forty years later, in the Baratayuda inscribed in 1890, helmet-donning soldiers are portrayed marching alongside their cannons, with Dutch flags flying in the background (see fig. 10). ${ }^{12}$

11 Ahmat B. Adam, The Vernacular Press and the Emergence of Modern Indonesian Consciousness (Ithaca: Cornell University SEAP, 1995) 89.

12 Cannons and Dutch flags sometimes appear in manuscripts dating to an earlier period. However, within the context of this particular collection, the appearance of such different illustrations in two manuscripts that tell the same story in an almost identical manner, seems to mark significant change. 


\section{Concluding Thoughts}

Besides reading manuscripts for their content - fascinating as it may bethey can also be read and analyzed as objects produced in a particular time and place that provide insight into particular practices, ideas and social histories. ${ }^{13}$ The exploration of Javanese paratexts offers a way to approach the broad questions of changing reading and writing patterns, ideas about information, circulation and transmission of knowledge in late nineteenth century Java.

Considering the evidence presented in this article let me return for a moment to Genette's words:

More than a boundary or a sealed border, the paratext is, rather, a threshold ... that offers the world at large the possibility of either stepping inside or turning back... It is an 'undefined zone' between the inside and outside ... an edge ... a fringe of the printed text which in reality controls one's whole reading of the text.

As Genette so articulately claimed, and as the Javanese paratexts considered exemplify, paratexts are not obscure, technical additions to a book or manuscript that exist for reasons of convenience or convention alone. They are indicators of a range of ideas and practices that together, if we look closely, can tell us something about how people read and understood the world. As thresholds to the text they frame it in certain ways and shape how people make sense of it, what they grow to anticipate and how they respond. Manuscripts in the Pakualam court at the turn of the twentieth century were becoming more like modern books—with title pages, brief introductions, authors' names, dates of inscription and page sequence all clearly noted-their spatial arrangement of the page and their attention to detail, number, time, category and individuality all marking shifts in societal attitudes towards authority, selfhood and creativity. Thus the paratexts explored here stand not only between reader and book as Genette

13 For an interesting example of the kind of information preserved in manuscript notes in an Achehnese collection (including documentation of births and deaths, information about an earthquake, various types of local knowledge), notes that attest to the intellectual legacy and everyday life of that region in the nineteenth century, see Fathurahman, Oman. 'Sisi Humanis Manuskrip Kitab Nusantara.' MANASSA website, 30.6.2011. http://www.manassa.org/main/sb/?detail= 20110630110541 
suggested but also as thresholds to a new era, signaling in their content and structure great changes, echoes of which we can almost hear as we turn the manuscripts' pages today.

\section{Bibliography}

\section{Manuscripts}

All manuscripts are from the Pura Pakualaman Library, Yogyakarta. Dates can refer to the dates of writing or copying. All references are to Sri Ratna Saktimulya (ed.), Katalog Naskah-Naskah Perpustakaan Pura Pakualaman. Jakarta: Yayasan Obor Indonesia, 2005.

- Babad Napoleyon. 1891, MS. Bb. 26

Depicts the military campaigns and victories of Napoleon Bonaparte and ends with his death (Saktimulya, p. 34).

- Babad Pakualaman jilid I. 1918, MS. Bb. 31

Chronicles the history of Pura Pakualaman from the anointment of Pakualam I by the British in 1813 until his death in 1829 and the anointment of his son as Pakualam II (Saktimulya, pp. 38-40).

- Babad Segaluh jilid I. 1897, MS. Bb. 35

The manuscript is divided into two parts. The first recounts the adventures of Prabu Banjaransari; the second is a list of synonyms (dasanama) of Javanese words for 'king' (Saktimulya, pp. 44-45).

- Babad Segaluh jilid II. 1897, MS. Bb. 36

Opens with the birth of Siyungwanara, son of Prabu Banjaransari whose tale was recounted in volume I. It goes on to depict the adventures of several other Javanese kings, and tells the well known stories of an heirloom that disappeared from the Majapahit court and the set of clothes owned by the Prophet Muhammad that was bequeathed to Sunan Kalijaga (Saktimulya, p. 45).

- Babad Sengkala. Undated, MS. Bb. 38

Begins with the arrival of Hindus in the as-of-yet uninhabited regions of the archipelago and goes on to depicts the arrival of Arabs who would convert the population to Islam. Cited from an 1888 Bramartani article (Saktimulya, pp. 47-48).

- Baratayuda. 1850 , MS. St. 11

Recounts the events leading up to the Great War of the Mahabharata, and depicts the battle itself. The text ends with Kresna's eight-fold teachings (asthabrata) to the Pandawas about the duties of kingship (Saktimulya, pp. 137-138).

- Baratayuda. 1890, MS. St. 14 
This manuscript is based on MS. St. 11 and is almost identical in content (Saktimulya, pp. 141-142)

- Dara Murtasiyah. 1908, MS.St. 28

Opens with the story of Murtasiyah and Sèh Ngarip and goes on to depict Sèh Ngarip's various encounters. There are sections devoted to mystical knowledge (Saktimulya, pp. 159-160).

- Kempalan Warni-Warni. Undated but after 1883, MS Ll 16

This is a compilation of several texts including genealogies of Javanese kings, lists of land owners, synonym lists, and sections from the moralistic poem Wedhatama (Saktimulya, pp. 245-246).

- Lokapala. 1899, MS. St. 40

Begins with the genealogy of Javanese kings going back to the prophet Adam and continues with the story of the conflict between the kingdom of Lokapala and the kingdom of Alengka, echoing with several episodes from the Ramayana (Saktimulya, pp. 171-172).

- Panji Jayengtilam. 1928, MS. St. 59

Recounts the adventures in love and war of Panji Asmarabangun (Saktimulya, pp. 190-191).

- Panji Panuba. 1897, MS. St. 61

Tells the story of Prabu Suryawisesa of Jenggala who once caught a fish that was in fact a hermit in disguise, bringing about various misfortunes upon the kingdom (Saktimulya, pp. 192-193).

- Serat Aji Pamasa. 1896, MS. St.73

Offers a history of Prabu Kusuma Wicitra who ruled in Kediri and includes teachings of kingship and servitude (Saktimulya, p. 203).

- Serat Sriyatna. 1941, MS. St.82

Chronicles the dates of birth, marriage, ascension to the throne and death of the rulers of the four royal houses of Yogyakarta and Surakarta. The manuscript was copied from a printed edition, published by Panti Pradipta in 1932 (Saktimulya, pp. 217).

Secondary Sources

Adam, Ahmat B. The Vernacular Press and the Emergence of Modern Indonesian Consciousness. Ithaca: Cornell University Press, 1995.

Arps, Bernard. Tembang in Two Traditions: Performance and Interpretation of Javanese Literature. London: School of Oriental and African Studies, 1992.

Behrend, T.E. 'The Writings of K. P. H. Suryanagara: Shifting Paradigms in Nineteenth Century Javanese Thought and Letters', in BKI 155/3 (1999): 390-415. - 'Manuscript Production in Nineteenth-Century Java: Codicology and the Writing of Javanese Literary History', in BKI 149/3 (1993): 407-37.

BKI = Bijdragen Koninklijk Instituut voor Taal-, Land-, en Volkenkunde (Leiden). 
Braginsky, V.I. 'Malay Scribes on Their Craft and Audience (with Special Reference to the Description of the Reading Assembly by Safirin Bin Usman Fadli)', in Indonesia and the Malay World 30/86 (2002): 37-61.

Chamber-Loir, Henri. 'Malay Colophons'. in Indonesia and the Malay World 34/100 (2006): 363-381.

Chartier, Roger, ed. The Culture of Print: Power and the Uses of Print in Early Modern Europe. Oxford: Polity Press, 1989.

Fathurahman, Oman. 'Sisi Humanis Manuskrip Kitab Nusantara' in MANASSA website, 30.6.2011. http://www.manassa.org/main/sb/?detail=20110630110541 (accessed January 29, 2012).

Febvre, Lucien and Henri-Jean Martin. The Coming of the Book: The Impact of Printing 1450-1800. 1958. Trans. David Gerard. London: NLB, 1976.

Gallop, Annabel Teh. 'The Art of the Qur'an in Southeast Asia', in Fahmida Suleman, ed. Word of God, Art of Man: The Qur'an and its Creative Expressions (Oxford: Oxford University Press, 2008) 192-204.

_ 'Qur'an Manuscripts from Mindanao in U.S Collections', in Our Own Voice website, April 2011. http://www.oovrag.com/essays/essay2011a-1.shtml (accessed January 25, 2012).

Gallop, Annabel Teh and Ali Akbar. 'The Art of the Qur'an in Banten: Calligraphy and Illumination', in Archipel 72 (2006): 95-135.

Genette, Gerard. Paratexts: Thresholds of Interpretation. 1987. Trans. Jane E. Lewin. Cambridge: Cambridge University Press, 1997.

Graaf, H.J. de. The Spread of Printing, Eastern Hemisphere: Indonesia. The Spread of Printing: A History of Printing Outside Europe in Monographs. Ed. Colin Clair. Amsterdam: Van Gendt \& Co., 1969.

Gray, Jonathan. 'Television Previews and the Meaning of Hype', in International Journal of Cultural Studies 11.1 (2008): 33-49.

Hernandez, Ramir. 'Disgusted with Modern History:' Paratexts, Intertexts and Ethics in the Transmission of Gulliver's Travels. Unpublished M.A thesis, University of California, Long Beach, 2009.

Isa, Zubaidah. Printing and Publishing in Indonesia: 1602-1970. Ph.D. Indiana University, Bloomington, 1972.

McCoy, Beth. 'Race and the (Para)Textual Condition', in PMLA 121/1 (2006): 156-169.

Nixon, Cheryl. "Stop a Moment at this Preface": The Gendered Para-texts of Fielding, Barker, and Haywood', in Journal of Narrative Theory 32.3 (2002): 123-153.

Noegraha, Nindya. Tradisi Penulisan Naskhah Jawa. Seminar Antarbangsa Manuskrip Melayu. 1995. Perpustakaan Negara Malaysia.

Paling, Stephen. 'Thresholds of Access: Paratextuality and Classification', in Journal of Education for Library and Information Science 43.2 (2002) 134-143.

Pigeaud, Theodore G.Th. Literature of Java. 4 vols. The Hague: Martinus Nijhoff, 1967-1970, 1980.

Poerbatjaraka, R.M.Ng. and Tardjan Hadidjaja. Kepustakaan Djawa. Jakarta: Djambatan, 1952.

Poerwokoesoemo, Soedarisman. Kadipaten Pakualaman. Yogyakarta: Gadjah Mada University Press, 1985. 
Proudfoot, Ian. 'From Recital to Sight-Reading: The Silencing of Texts in Malaysia', in Indonesia and the Malay World 30/87 (2002): 117-44.

Saktimulya, Sri Ratna. Fungsi Wedana Renggan Dalam Sestradisuhul. M.A. Yogyakarta: Gadjah Mada, 1998.

Saktimulya, Sri Ratna, ed. Katalog Naskah-Naskah Perpustakaan Pura Pakualaman. Jakarta: Yayasan Obor Indonesia, 2005. 


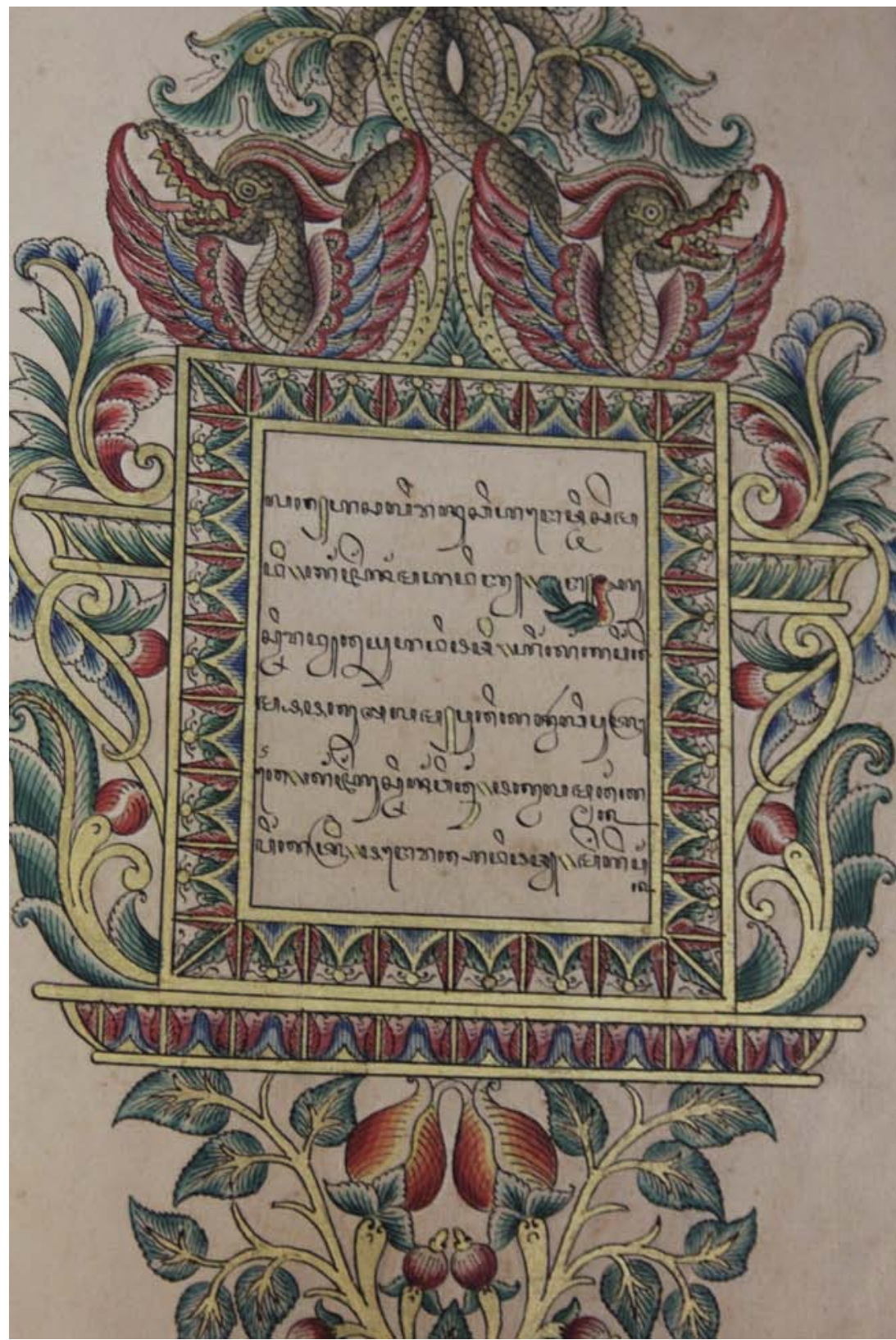

Fig. 1. Gapura renggan ('adorned gateway'). Babad Pakualaman, 1918, MS Yogyakarta, Perpustakaan Pura Pakualaman, Bb.31 


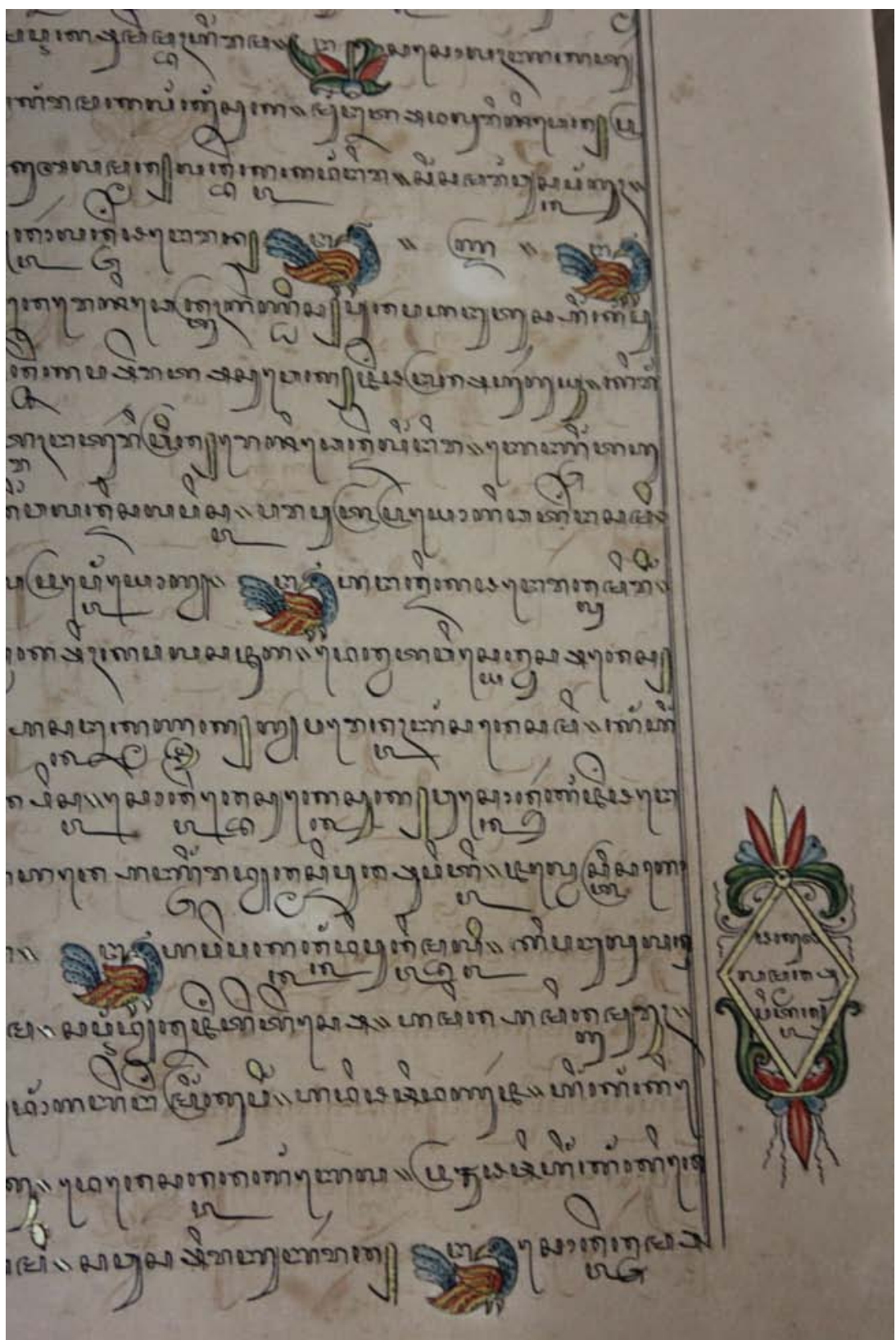

Fig. 2. Rubrikasi and stanza markers. Babad Pakualaman, 1918, MS Yogyakarta, Perpustakaan Pura Pakualaman, Bb.31. 


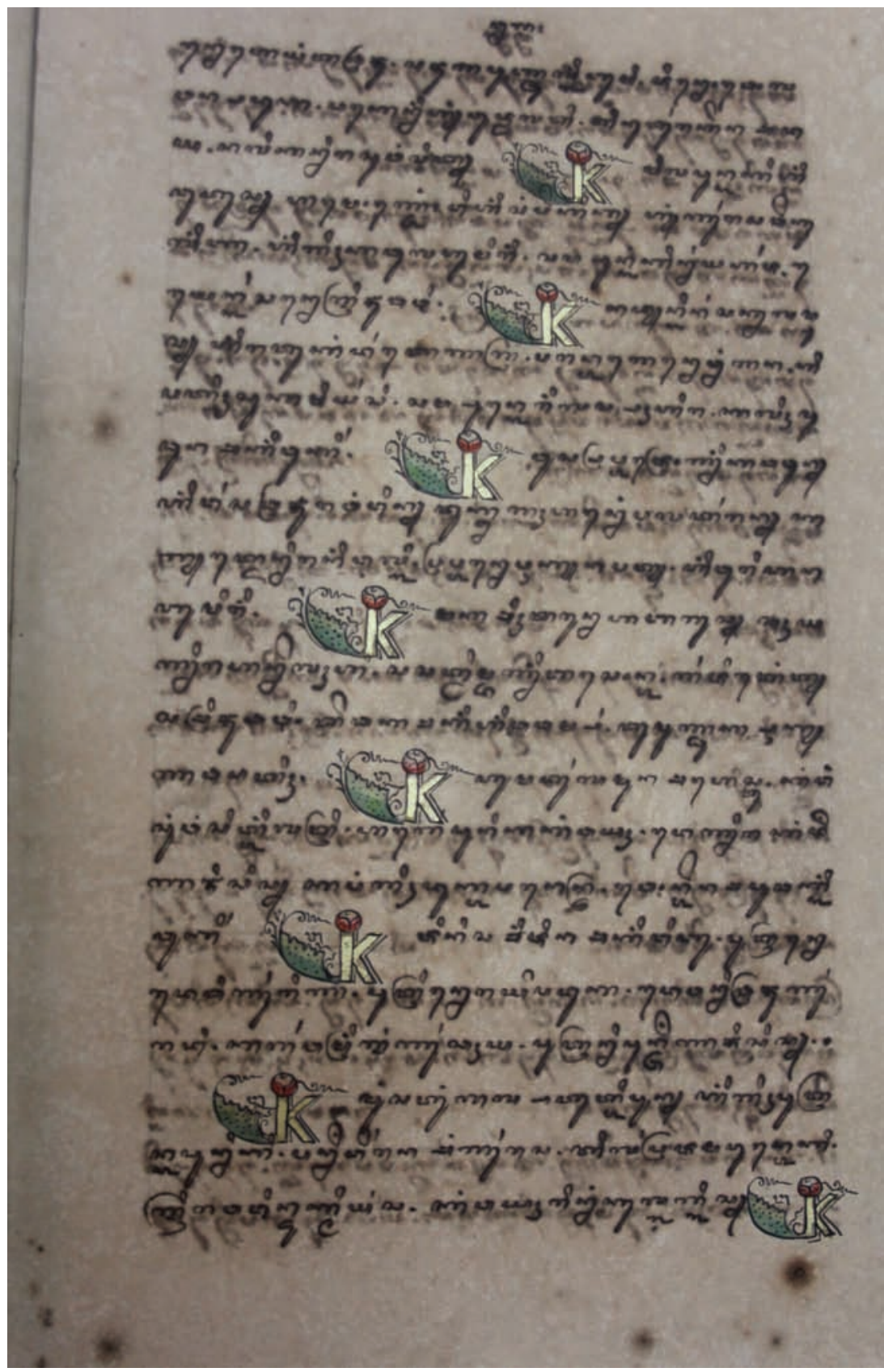

Fig. 3. Stanza markers in the form of the letter 'K'. Lokapala, 1899, MS Yogyakarta, Perpustakaan Pura Pakualaman, St. 40. 


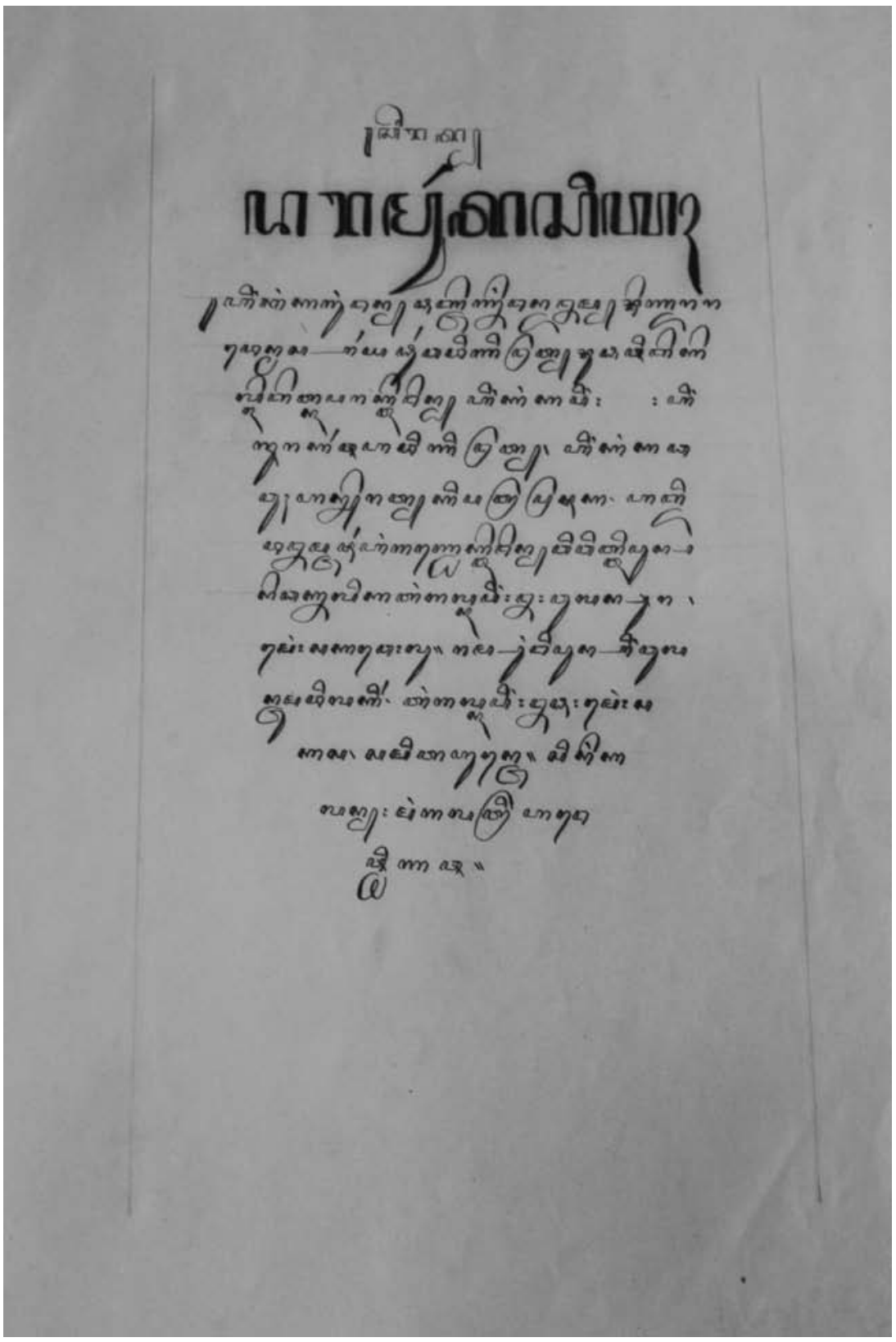

Fig. 4. Title page. Dara Murtasiyah, 1908, MS Yogyakarta, Perpustakaan Pura Pakualaman, St. 28. 


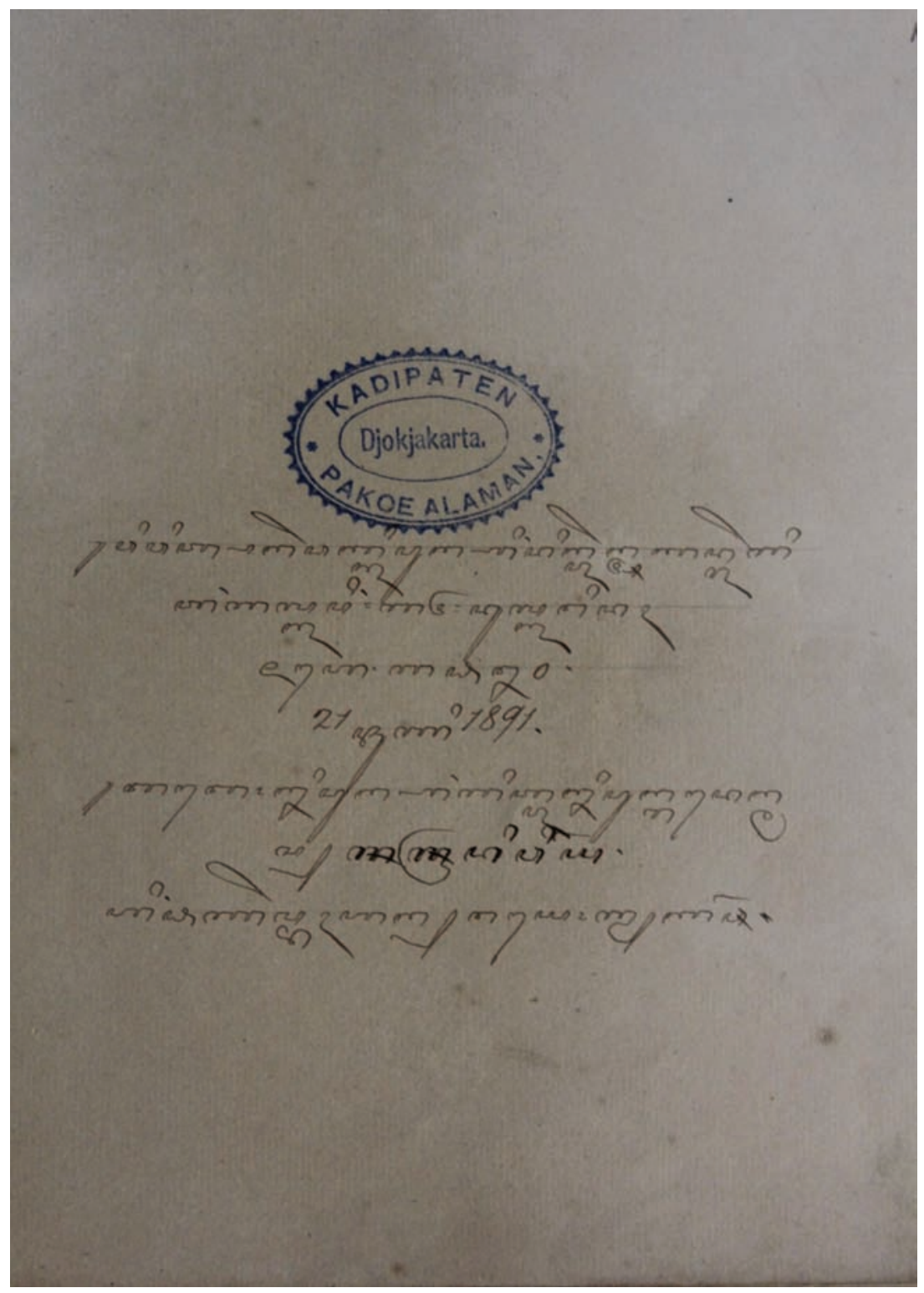

Fig. 5. Highlighting of author's name. Babad Napoleyon, 1892, MS Yogyakarta, Perpustakaan Pura Pakualaman, St. 26. 


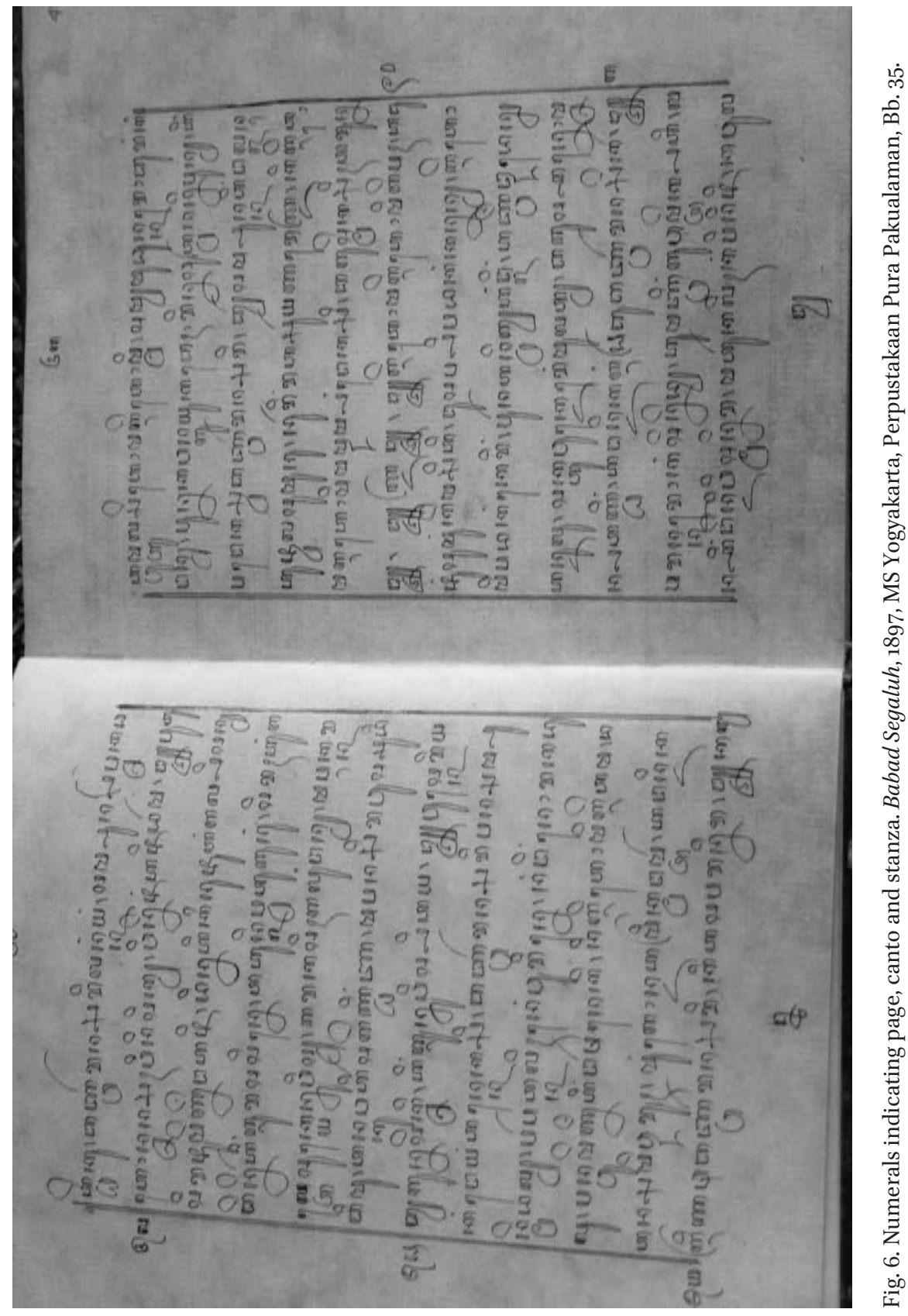




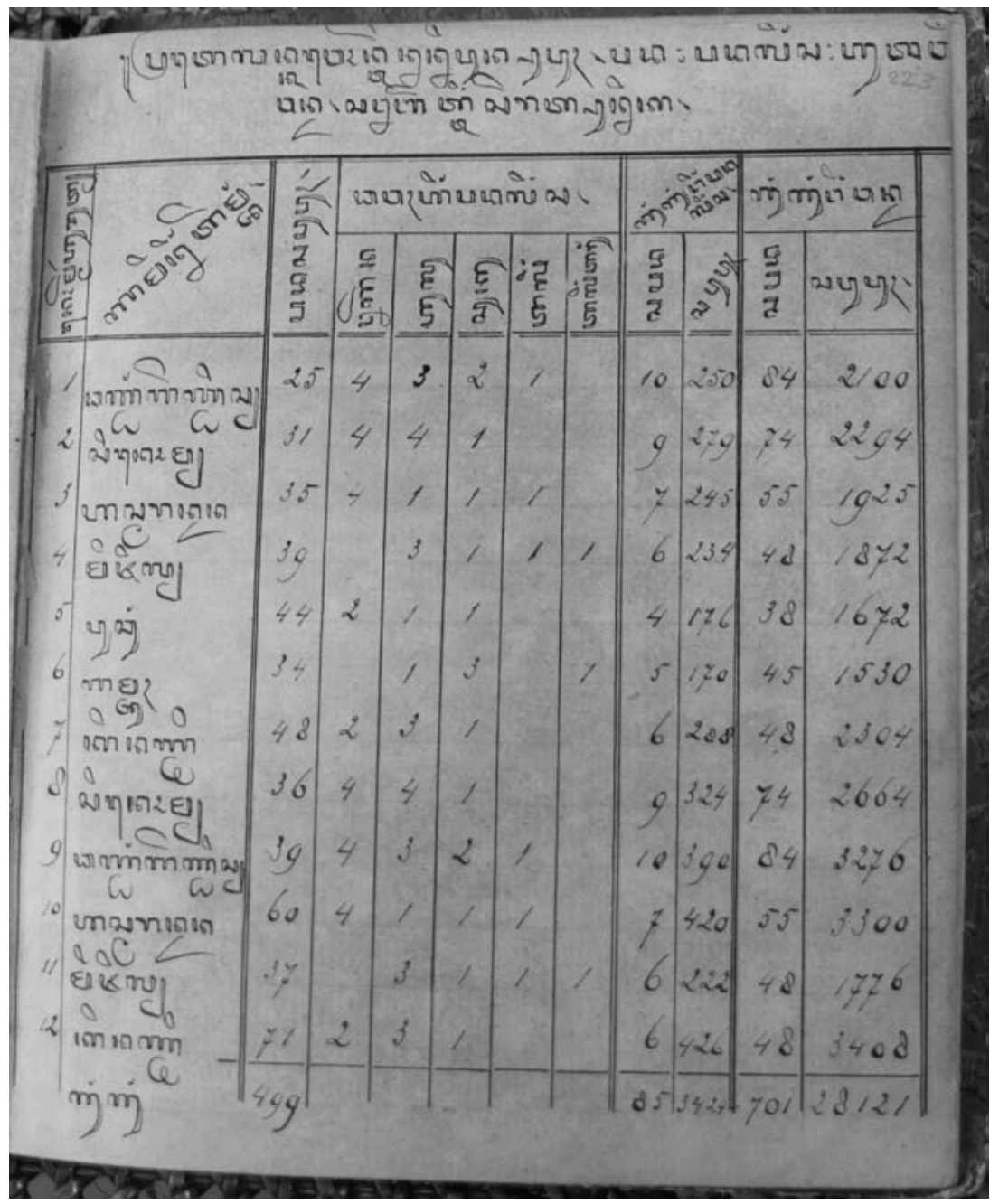

Fig. 7. Pratélan. Panji Panuba, 1897, MS Yogyakarta, Perpustakaan Pura Pakualaman, St. 61. 


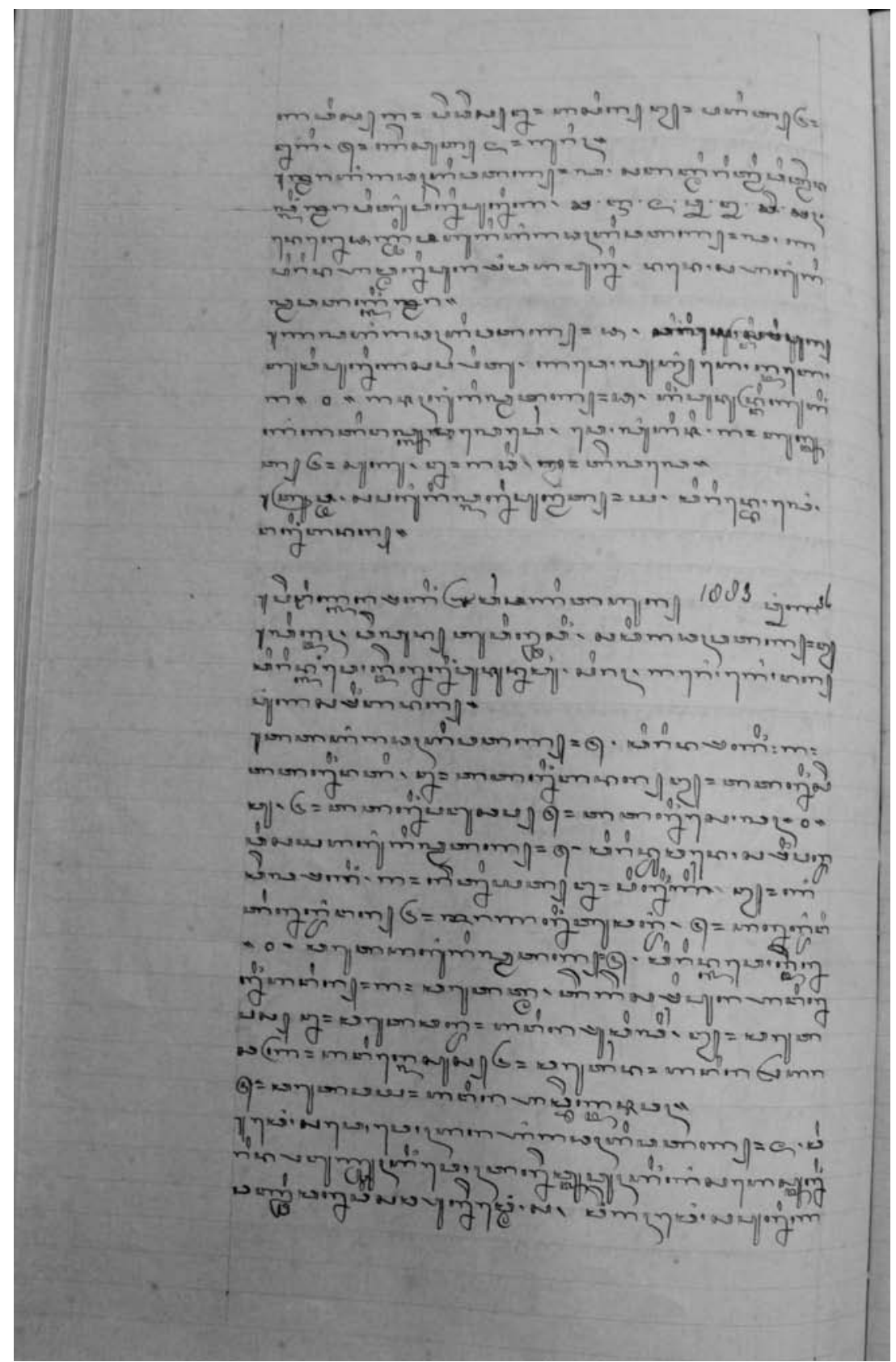

Fig. 8. Citation from an 1883 Bramartani issue. Kempalan Warni-Warni, undated, MS Yogyakarta, Perpustakaan Pura Pakualaman, Ll. 16. 


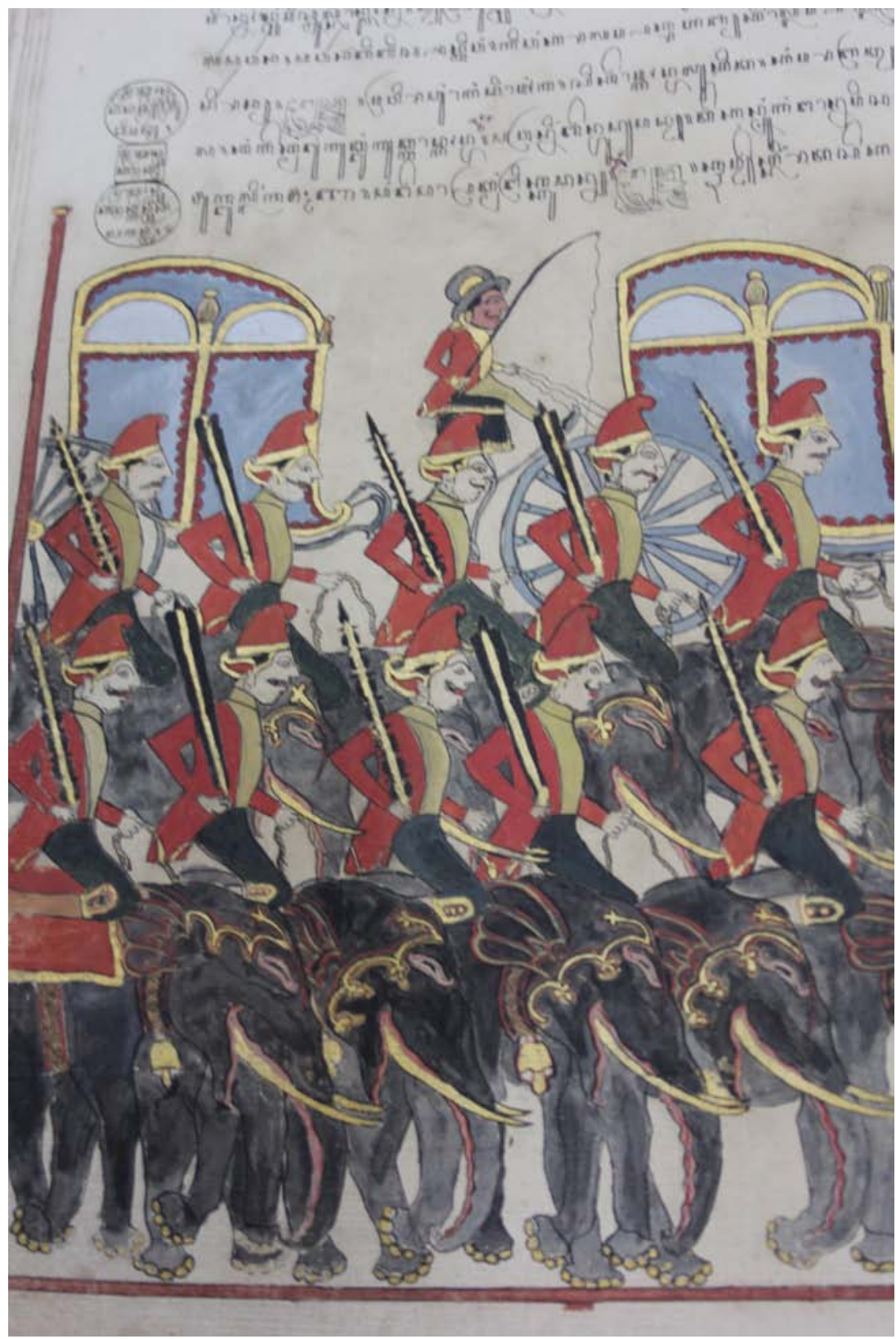

Fig. 9. Scene from the Great War. Baratayuda, 1850, MS Yogyakarta, Perpustakaan Pura Pakualaman, St. 11. 


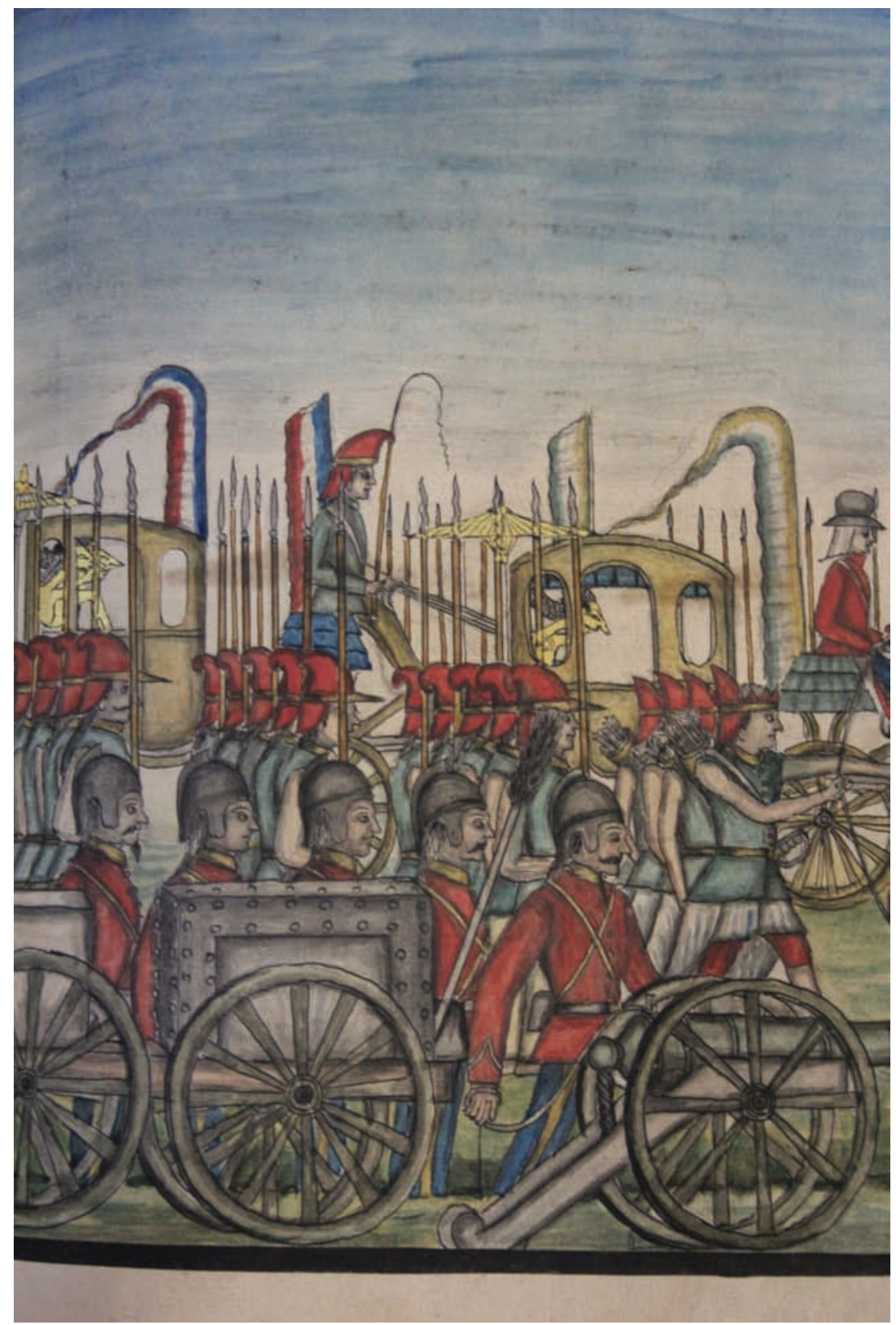

Fig. 10. Scene from the Great War, forty years onwards. Baratayuda, 1890, MS Yogyakarta, Perpustakaan Pura Pakualaman, St. 14. 